\title{
A Simple Case Study of Material Requirement Planning
}

\author{
Asis Sarkar ${ }^{1}$, Dibyendu Das ${ }^{2}$, Sujoy Chakraborty ${ }^{3}$, Nabarun Biswas ${ }^{4}$ \\ 1,2,3,4 Assistant Professor \\ ${ }^{1,2}$ Department of Mechanical Engineering, ${ }^{3}$ Department of Production Engineering, N.I.T.Agartala, Jirania, \\ Barjala-799055, Tripura, India. \\ ${ }^{4}$ Department of Mechanical Engineering \\ N.I.T.M.A.S, Dimond Harbour, West Bengal, India.
}

\begin{abstract}
A material requirement planning is a technique that uses the bill of material, inventory data and a master schedule to calculate requirements for material. It also takes into account the combination of the bill of material structure and assembly lead times. The result of an MRP plan is a material plan for each item found in the bill of material structure which indicates the amount of new material required, the date on which it is required. The new schedule dates for material that is currently on order. If routings, with defined labor requirements are available, a capacity plan will be created concurrently with the MRP material plan. The MRP plan can be run for any number entities (which could be physically separated inventories) and can include distributor inventories, if the system has access to this type of information. MRP tries to strike the best balance possible between optimizing the service level and minimizing costs and capital lockup. In this paper it is tried to present a practical M.R.P. problem and is shown how it is helpful in optimizing the service level and minimizing costs.
\end{abstract}

Keywords: material requirement planning; inventory; bill of materials; master schedule; optimizing.

\section{Introduction}

Traditionally, manufacturing companies have controlled their parts through the reorder point (ROP) technique. Gradually, they recognized that some of these components had dependent demand, and material requirements planning (MRP) evolved to control the dependent items more effectively. MRP has been a very popular and widely used multilevel inventory control method since 1970s. The application of this popular tool in materials management has greatly reduced inventory levels and improved productivity (Wee and Shum, 1999).The introduced MRP was the first version of MRP system, named as Materials Requirements Planning (MRP I). Later, several MRP systems were extended into other versions including Manufacturing Resources Planning (MRP II) and Enterprise Resources Planning (ERP) (Browne et al., 1996). MRP is a commonly accepted approach for replenishment planning in major companies. The MRP based software tools are accepted readily. Most industrial decision makers are familiar with their use. The practical aspect of MRP lies in the fact that this is based on comprehensible rules, and provides cognitive support, as well as a powerful information system for decision

Materials requirements planning (MRP) is an inventory planning and control technique developed to deal with dependent-demand inventories. An MRP system, in its simplest form, consists of three basic components: a master production schedule (MPS); bill-of-material (BOM) files of the end items; and inventory status files of various materials, components, parts, subassemblies and final products [I]. The MPS is a product requirements schedule compiled from both firm customer orders and tentative demand forecasts. It is a listing of the demand for the end items in each of the time periods over a planning horizon. Given the MPS, the requirements of the lower-level components and parts can be derived using the information contained in the various BOM files. These lower-level material requirements are then backward scheduled into the appropriate time periods according to the planned lead times specified in the BOM. These time-phased gross material requirements are modified by the amount of materials on hand and on order for each time period by consulting the inventory status files. The net requirements of each material in each time period can then be computed. Finally, orders are placed for materials with positive net requirements. An important decision problem in MRP is determining the size of production lots from the net requirements. A production lot is a batch of parts continuously produced under the same operating conditions. The problem of determining the quantities of parts to be processed in a batch and the times of completing these batches is commonly referred to as the lot-sizing problem in the literature.

One of its main objectives is to keep the due date equal to the need date, eliminating material shortages and excess stocks. MRP breaks a component into parts and subassemblies, and plans for those parts to come into stock when needed. Material requirement planning systems help manufactures determine precisely when and how much material to purchase and process based upon a time phased analysis of sales orders, production 
orders, current inventory and forecasts. They ensure that firms will always have sufficient inventory to meet production demands, but not more than necessary at any given time. MRP will even schedule purchase orders and/or production orders for Just in time receipt.

\section{Related Literature}

There is substantial amount of literature available on Materials Management and MRP in the form of research papers, books and articles in Journals etc. Some important methods are: MRP needs for Make-to-Order Company, J Hoey, B.R. Kilmarting and R.Leonard (1986), Scheduling and order Release, James R. Ashby (1995). For determining the role of inventory safety stock on MRP: Optimal positioning of safety stock in MRP, A.G. Lagodimos and E.J. Anderson (1993), product Structure Complexity W.C. Benton and R. Srivastava (1993).

Yenisey (2006) applied a flow network model and solved a linear programming method for MRP problems that minimized the total cost of the MRP system. Mula et al. (2006) provided a new linear programming model for medium term production planning in a capacity constrained MRP with a multiproduct, multilevel, and multi period production system. Their proposed model comprised three fuzzy sub models with flexibility in the objective function, market demand, and capacity of resources. Wilhelm and Som (1998) present an inventory control approach for an assembly system with several types of components. Their model focuses on a single finished product inventory, so the interdependence between inventory levels of different components is once again neglected. Axsater (2005) considers a multi level assembly system where operation times are independent random variables. The objective is to choose starting times (release dates) for different operations in order to minimize the sum of the expected holding and backlogging costs. Kanet and Sridharan (1998) examined late delivery of raw materials, variations in process lead times, interoperation move times and queue waiting times in MRP controlled manufacturing environment. To model such environment, they represented demand by inter arrival time rather than defined from the master production schedule. Kumar (1989) studies a single period model (one assembly batch) for a multi component assembly system with stochastic component lead times and a fixed assembly due date and quantity. The problem is to determine the timing of each component order so that the total cost composed of the component holding and product tardiness costs is minimized. Chauhan et al. (2009), presents an interesting single period model. Their approach considers a punctual fixed demand for one finished product. Multiple types of components are needed to assemble this product. The objective is to determine the ordering time for each component such as to minimize the sum of expected holding and backlogging cost. Van Donselaar and Gubbels (2002) compare MRP and line requirements planning (LRP) for planning orders. Their research basically focuses on minimizing the system inventory and system nervousness. They also discuss and propose LRP technique to achieve their goals. Minifie and Davies (1990) developed a dynamic MRP controlled manufacturing system simulation model to study the interaction effects of demand and supply uncertainties. These uncertainties were modeled in terms of changes in lot size, timing, planned orders and policy fence on several system performance measures, namely late deliveries, number of setups, ending inventory levels, component shortages and number of exception reports.

Billing ton et al. (1983) suggested a mathematical programming approach for scheduling capacity constrained MRP systems. They propose a discrete time, mixed integer linear programming formulation. In order to reduce the number of variables, and thus the problem size, they introduce the idea of product structure compression.

\section{Materials and Methods}

Let us consider that a company produces a final product $\mathrm{X}$. Each unit of product $\mathrm{X}$ requires some component of $\mathrm{Y}$. If it takes, two months to produce a unit of $\mathrm{X}$ and one month for a unit of $\mathrm{Y}$ within a certain period of $t$ months, the initial stock level of $X$ is $X$ quantity, and it is the units of $X$ scheduled for receipts at the beginning of month $t$ to avoid shortages.

Let $\mathrm{NR}_{t}(\mathrm{X})=$ Net requirement of $\mathrm{X}$ for the period $\mathrm{t}$

$\mathrm{GR}_{\mathrm{t}}(\mathrm{X})=$ Gross requirement of $\mathrm{X}$ during period $\mathrm{t}$

$\mathrm{SR}_{t}(\mathrm{X})=$ Schedule requirement of $\mathrm{X}$ during period $\mathrm{t}$

$\mathrm{OH}_{\mathrm{t}}(\mathrm{X})=$ On hand inventory of $\mathrm{X}$ at the end of period $\mathrm{t}$

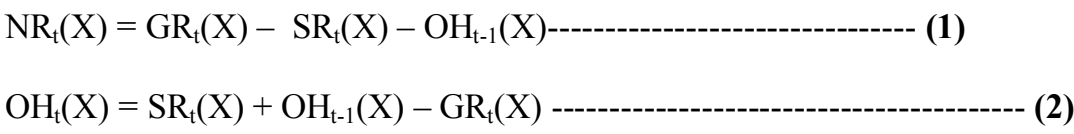

The problem of material requirement planning can be solved by the following steps:

Step I: Draw the Product structure tree and determine the end product requirement from the master production schedule or by forecasting method for different periods. 
Step II: Determine the subcomponent requirement from Product structure tree.

Step III: Compute the decision matrix table with different periods in the vertical columns and projected requirement, On hand availability, schedule receipts and planned order release in the horizontal row side.

Step IV: Complete the MRP table by applying equation (1) and (2) and by filling all the vacant cells.

\section{Case Study:}

The manufacturing of a car assembly requires one unit of flywheel, two unit of wheel assembly, one unit of engine lock assembly, one unit of water pump assembly. Each unit of wheel assembly requires one unit of wheel and four units of bearings. Each engine block assembly requires two unit of shaft and 4 units of bearings. Each unit of water pump assembly requires a bearing of same type \& price as that of engine block assembly and is designated as (E). The wheel assembly is designated here as ( C ), flywheel unit is designated as(B), engine block assembly is designated as (D) and water pump assembly is designated as (I). Wheel is designated as (F) and bearing is designated as $(\mathrm{G})$, shaft is designated as $(\mathrm{H})$ and engine bearing is also designated as (E) like water pump bearing because of same type \& price. The product structure tree is designated as follows: -

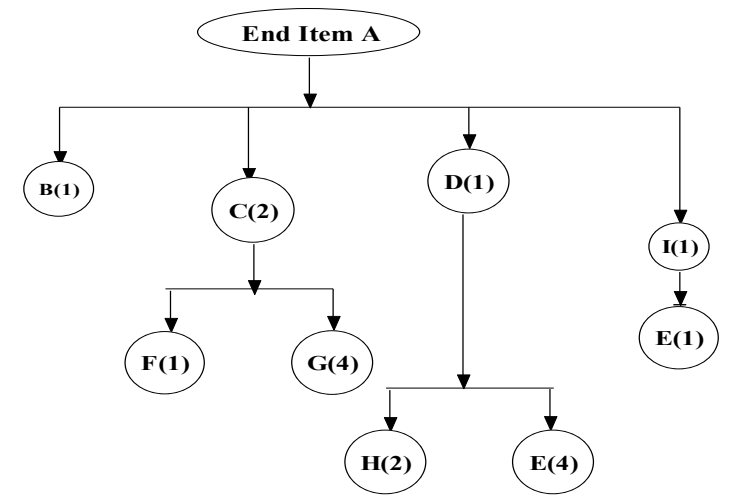

Figure 1: The Product Structure Tree

Designation: A = car assembly, B: Flywheel unit, C: wheel assembly, D: Engine block assembly, I: Water pump assembly, F: wheel, H: shaft, G: Wheel assembly bearing, E: Engine block assembly bearing.

The other informations available are shown in Table 1.

Table 1: Information about ordering quantity, lead time, safety stock to be kept and available quantity at the beginning of different components and subcomponents of car assembly (the end item)

\begin{tabular}{|c|c|c|c|c|}
\hline Component & Ordering quantity & Lead Time & Safety stock & $\begin{array}{l}\text { Available quantity at the } \\
\text { beginning }\end{array}$ \\
\hline A & variable & 1 week & 0 & 0 \\
\hline B & 450 & 2 weeks & 120 & 120 \\
\hline C & 1000 & 2 weeks & 200 & 600 \\
\hline D & 500 & 1 week & 40 & 120 \\
\hline E & 2500 & 1 week & 120 & 120 \\
\hline F & 1000 & 2 weeks & 120 & 200 \\
\hline G & 5000 & 2 weeks & 200 & 240 \\
\hline H & 1000 & 2 weeks & 120 & 120 \\
\hline I & 500 & 2 weeks & 120 & \\
\hline
\end{tabular}

Now it is the task of management to design a M.R.P. system for the whole unit. The Master schedule drives the MRP system by establishing the Demand. The projected demand for 10 periods is stated below and it is derived from external orders already received. The end product requirement for the 10 month period is shown in Table 2.

Table 2: End Product requirement for the 10 month period

\begin{tabular}{|ll|l|l|l|l|l|l|l|l|l|l|}
\hline Time & 1 & 2 & 3 & 4 & 5 & 6 & 7 & 8 & 9 & 10 \\
\hline $\begin{array}{l}\text { End Product } \\
\text { requirement }\end{array}$ & & 200 & 300 & & 500 & & 400 & & & 600 \\
\hline
\end{tabular}

\section{Calculation:}

The demands for various subcomponents are stated below. Assuming that Product A has a one week lead time and can be produced in lot sizes equal to demand. Then components $\mathrm{B}, \mathrm{C}, \mathrm{D}$, have a dependent demand equal to the demand A but occurring one week earlier. The Projected requirement of B is shown in 
Table no 3. Because one unit of component B required for each unit of end items as prescribed in product structure tree. The requirements are shown as an offset of one week earlier.

Table 3: The demand for component $B$

\begin{tabular}{|l|l|l|l|l|l|l|l|l|l|l|}
\hline $\begin{array}{l}\text { Component B, Order quantity variable } \\
\text { Lead Time:-0 }\end{array}$ & 1 & 2 & 3 & 4 & 5 & 6 & 7 & 8 & 9 & 10 \\
\hline Projected requirements & 200 & 300 & & 500 & & 400 & & & 600 & \\
\hline
\end{tabular}

Similarly the projected requirement of $\mathrm{D}$ is shown in Table no 4 . Because one unit of component D required for each unit of end items as prescribed in product structure tree. The requirements are shown as an offset of one week earlier.

Table 4: The demand for component $D$

\begin{tabular}{|l|l|l|l|l|l|l|l|l|l|l|}
\hline $\begin{array}{l}\text { Component D, Order quantity }=500, \text { Lead } \\
\text { Time }=1 \text { week, Safety stock }=40\end{array}$ & 1 & 2 & 3 & 4 & 5 & 6 & 7 & 8 & 9 & 10 \\
\hline Projected requirements & 200 & 300 & & 500 & & 400 & & & 600 & \\
\hline
\end{tabular}

Similarly, the projected requirement of $\mathrm{C}$ is shown in Table no 5. As because two units of component $\mathrm{C}$ is required for each unit of end items as prescribed in product structure tree, the requirement is shown as an offset of one week earlier.

Table 5: The demand for component $\mathrm{C}$

\begin{tabular}{|c|c|c|c|c|c|c|c|c|c|c|}
\hline \multirow{2}{*}{$\begin{array}{l}\text { Component } \mathrm{C} \text {, } \\
\text { Lead Time }=2 \text { weeks }\end{array}$} & \multicolumn{10}{|c|}{ Week numbers } \\
\hline & 1 & 2 & 3 & 4 & 5 & 6 & 7 & 8 & 9 & 10 \\
\hline Projected requirement & 400 & 600 & & 1000 & & 800 & & & 1200 & \\
\hline
\end{tabular}

Similarly, the projected requirements of I are shown in Table no 6. As because one unit of component I is required for each unit of end items as prescribed in product structure tree, the requirement is shown as an offset of one week earlier.

Table 6: The demand for component I

\begin{tabular}{|l|l|l|l|l|l|l|l|l|l|l|}
\hline $\begin{array}{l}\text { Component I, Order quantity }=500, \\
\text { Lead Time }=1 \text { week, Safety stock }=40\end{array}$ & & & 3 & 4 & 5 & 6 & 7 & 8 & 9 & 10 \\
\hline Projected requirements & 200 & 300 & & 500 & & 400 & & & 600 & \\
\hline
\end{tabular}

Similarly, the projected requirement of $\mathrm{F}$ is shown in Table no 7. Because one unit of component $\mathrm{F}$ is required for each unit of end item $\mathrm{C}$ as prescribed in the product structure tree and in total two units of item $\mathrm{F}$ is required because two units of component $\mathrm{C}$ is required for each unit of end item $\mathrm{A}$. To find out when to produce subcomponent $\mathrm{G}$ and $\mathrm{F}$, it is first necessary to determine the order release dates for component $\mathrm{C}$. A combination of material requirement plan for end item $\mathrm{A}$, item $\mathrm{C}$, item $\mathrm{F}$, and item $\mathrm{G}$ is presented in the result section.

Table 7: The demand for component $F$

\begin{tabular}{|c|c|c|c|c|c|c|c|c|c|c|}
\hline \multirow{2}{*}{$\begin{array}{l}\text { Sub-Component }=\mathrm{F}, \text { Lead } \\
\text { Time }=2 \text { weeks }\end{array}$} & \multicolumn{10}{|c|}{ Week numbers } \\
\hline & 1 & 2 & 3 & 4 & 5 & 6 & 7 & 8 & 9 & 10 \\
\hline
\end{tabular}

Similarly, the projected requirement of $G$ is shown in Table no 8. Because four units of item $G$ is required for each unit of end item $\mathrm{C}$ as prescribed in product structure tree and the total item $\mathrm{G}$ required are eight units because two unit of component $\mathrm{C}$ are required for each unit of end items $\mathrm{A}$. .

Table 8: The demand for component $G$

\begin{tabular}{|c|c|c|c|c|c|c|c|c|c|c|}
\hline \multirow{2}{*}{$\begin{array}{l}\text { Sub-Component }=\mathrm{G} \\
\text { Lead Time }=2 \text { weeks }\end{array}$} & \multicolumn{10}{|c|}{ Week numbers } \\
\hline & 1 & 2 & 3 & 4 & 5 & 6 & 7 & 8 & 9 & 10 \\
\hline Projected requirement & & 4000 & & 3200 & & & 4800 & & & \\
\hline
\end{tabular}

It seems that each unit of $\mathrm{D}$ requires 2 units of $\mathrm{H}$. The material requirement planning of item $\mathrm{H}$ is presented in Table no 9.

Table 9: The demand for component $H$

\begin{tabular}{|c|c|l|l|l|l|l|l|l|l|l|l|l|}
\hline $\begin{array}{l}\text { Component } \\
\text { quantity }=500\end{array}$ & $\mathrm{H}$, Order & 1 & 2 & 3 & 4 & 5 & 6 & 7 & 8 & 9 & 10 \\
\hline
\end{tabular}




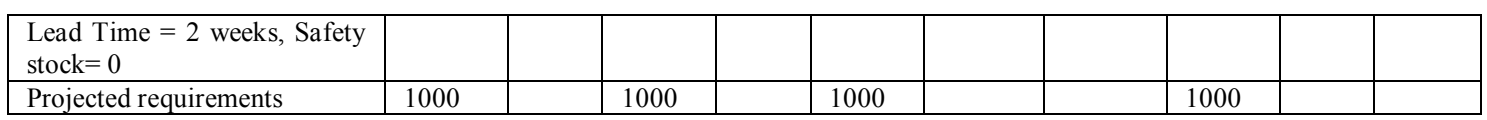

The product structure tree and bill of material figure indicate that one unit of $\mathrm{E}$ is required for the assembly of each unit of component A. 4 units of component $\mathrm{E}$ are used for manufacturing component D. It is assumed that the previously used order releases are applicable for A and D. So order release quantity of product $\mathrm{D}$ is multiplied by 4 and the requirement for order release of $\mathrm{A}$ are offset to account the lead time. So requirement of $\mathrm{E}$ is the total projected requirement of $\mathrm{A}$ and $\mathrm{D}$. Here the order release of each component of $\mathrm{D}$ is multiplied by 4 to get the number of units of $\mathrm{E}$. The requirement of $\mathrm{E}$ is shown in Table no 10.

Table 10: demand for component $E$

\begin{tabular}{|l|l|l|l|l|l|l|l|l|l|l|}
\hline Week & 1 & 2 & 3 & 4 & 5 & 6 & 7 & 8 & 9 & 10 \\
\hline $\begin{array}{l}\text { Requirement of item E for } \\
\text { assembly of each unit of end item } \\
\text { A and I }\end{array}$ & 200 & 300 & & 500 & & 400 & & & 600 & \\
\hline $\begin{array}{l}* * \text { Requirement of 4 nos. of item E } \\
\text { for assembly of each unit of item } \\
\text { D }\end{array}$ & 2000 & & 2000 & & 2000 & & & 2000 & & \\
\hline $\begin{array}{l}\text { Total projected requirement of } \\
\text { item E for assembly of one unit of } \\
\text { end item A }\end{array}$ & 2200 & 300 & 2000 & 500 & 2000 & 400 & & 2000 & 600 & \\
\hline
\end{tabular}

Table: - 11: Estimation of projected demand, scheduled receipt and planned order release of item B

Table 12: Estimation of projected demand, scheduled receipt and planned order release of item D

\begin{tabular}{|c|c|c|c|c|c|c|c|c|c|c|}
\hline $\begin{array}{l}\text { Component D } \\
\text { Order quantity }=500\end{array}$ & 1 & 2 & 3 & 4 & 5 & 6 & 7 & 8 & 9 & 10 \\
\hline 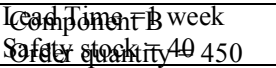 & 1 & 2 & 3 & 4 & 5 & 6 & 7 & 8 & 9 & 10 \\
\hline Prejactëinreequireneshts & 200 & 300 & & 500 & & 400 & & & 600 & \\
\hline Aprajbatbde requiflendents & 2600 & 3020 & 620 & 562800 & 620 & 4000 & 720 & 720 & 6000 & 620 \\
\hline SybadubateeeipssS=120 & $5 \overline{700}$ & $3 \overline{\not B 00}$ & 520 & 95900 & 4770 & 920 & 520 & 520 & (590 & 370 \\
\hline PAaheddlendererptease & 4500 & & 4500 & 450 & 500 & 450 & & 500 & 450 & \\
\hline Planned order release & 450 & 450 & & 450 & & & 450 & & & \\
\hline
\end{tabular}

Table 13: Estimation of projected demand, scheduled receipt and planned order release of item $\mathbf{E}$

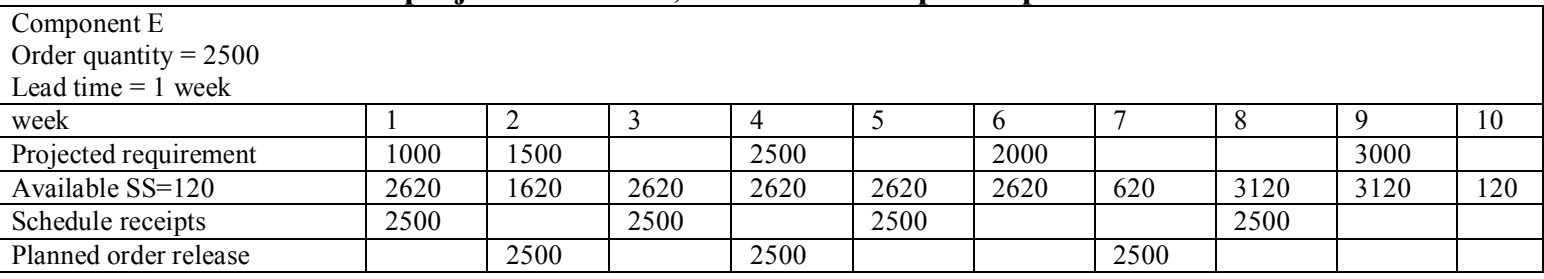

Table 14: Estimation of projected demand, scheduled receipt and planned order release of item $C, F \& G$

\begin{tabular}{|c|c|c|c|c|c|c|c|c|c|c|}
\hline \multirow{2}{*}{$\begin{array}{l}\text { End item }=\mathrm{A} \\
\text { Lead Time }=1 \text { week } \\
\text { Order quantity }= \\
\text { variable } \\
\text { Safety stock }=0\end{array}$} & \multicolumn{10}{|c|}{ Week numbers } \\
\hline & 1 & 2 & 3 & 4 & 5 & 6 & 7 & 8 & 9 & 10 \\
\hline Projected requirements & & 200 & 300 & & 500 & & 400 & & & 600 \\
\hline \multicolumn{11}{|l|}{ Available $=0$} \\
\hline Scheduled receipts & & 200 & 300 & & 500 & & 400 & & & 600 \\
\hline Planned order release & 200 & 300 & & 500 & & 400 & & & 600 & \\
\hline
\end{tabular}

(2C/A)

\begin{tabular}{|c|c|c|c|c|c|c|c|c|c|c|}
\hline \multirow{2}{*}{$\begin{array}{l}\text { Component }=\mathrm{C} \\
\text { Lead Time }=2 \text { weeks } \\
\text { Order quantity }=1000 \\
\text { Safety stock }=200\end{array}$} & \multicolumn{10}{|c|}{ Week numbers } \\
\hline & 1 & 2 & 3 & 4 & 5 & 6 & 7 & 8 & 9 & 10 \\
\hline Available $=600$ & 1600 & 1200 & 600 & 1600 & 600 & 1600 & 200 & 200 & 1200 & 1000 \\
\hline Scheduled receipt & 1000 & & & 1000 & & 1000 & & & 1000 & 1000 \\
\hline Planned order release & & 1000 & & 1000 & & & 1000 & 1000 & & \\
\hline
\end{tabular}


$(\mathbf{F} / \mathbf{C})$

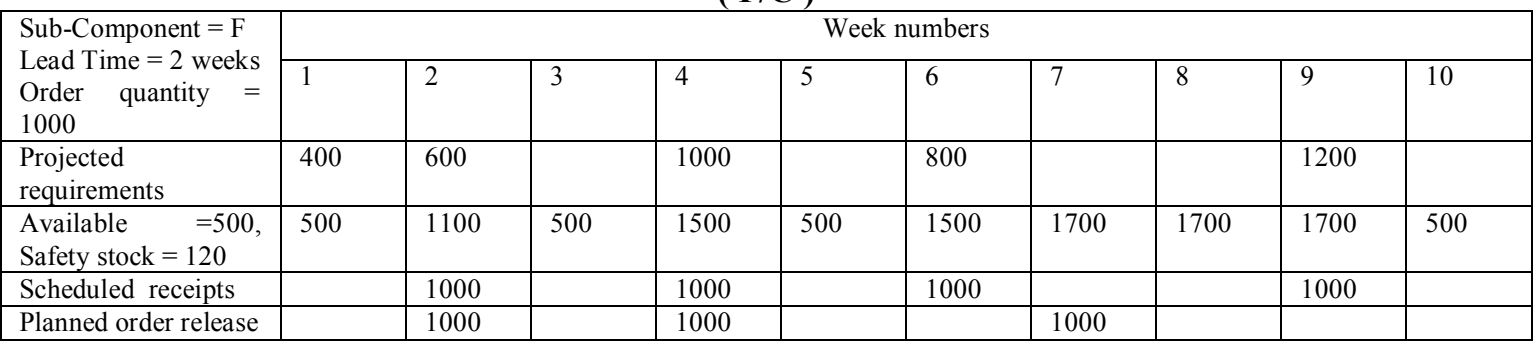

$(4 \mathrm{G} / \mathrm{C})$

\begin{tabular}{|c|c|c|c|c|c|c|c|c|c|c|}
\hline \multirow{2}{*}{$\begin{array}{l}\text { Sub-Component }=\mathrm{G} \\
\text { Lead Time }=2 \text { weeks } \\
\text { Order quantity }=5000\end{array}$} & \multicolumn{10}{|c|}{ Week numbers } \\
\hline & 1 & 2 & 3 & 4 & 5 & 6 & 7 & 8 & 9 & 10 \\
\hline $\begin{array}{l}\text { Projected } \\
\text { requirements }\end{array}$ & 1600 & 2400 & & 4000 & & 3200 & & & 4800 & \\
\hline $\begin{array}{l}\text { Available }=2000, \\
\text { safety stock }=200\end{array}$ & 2000 & 4400 & 4400 & 8400 & 4400 & 4400 & 5200 & 5200 & 5200 & 400 \\
\hline Scheduled receipt & & 4000 & & 4000 & & & 4000 & & & \\
\hline
\end{tabular}

Table 15: Estimation of projected demand, scheduled receipt and planned order release of item $D \&$ H

\begin{tabular}{|l|l|l|l|l|l|l|l|l|l|l|}
\hline $\begin{array}{l}\text { Component D } \\
\text { Order quantity =500 } \\
\begin{array}{l}\text { Lead Time =1 week } \\
\text { Safety stock =40 }\end{array}\end{array}$ & 1 & 2 & 3 & 4 & 5 & 6 & 7 & 8 & 9 & 10 \\
\hline Projected requirement & 200 & 300 & & 500 & & 400 & & & 600 & \\
\hline Available = 40, SS = 120 & 620 & 920 & 620 & 620 & 620 & 1120 & 720 & 720 & 1220 & 620 \\
\hline Schedule receipt & 500 & 500 & & 500 & & 500 & & & 500 & \\
\hline Planned order release & 500 & & 500 & & 500 & & & 500 & & \\
\hline
\end{tabular}

(2H/D)

\begin{tabular}{|l|l|l|l|l|l|l|l|l|l|l|}
\hline $\begin{array}{l}\text { Component } \mathrm{H} \\
\text { Order quantity =1000 } \\
\text { Lead Time =2 week } \\
\text { Safety stock =120 }\end{array}$ & 1 & 2 & 3 & 4 & 5 & 6 & 7 & 8 & 9 & 10 \\
\hline Projected requirement & 400 & 600 & & 1000 & & 800 & & & 1200 & \\
\hline Available = SS, 240 & 1240 & 840 & 240 & 1240 & 1240 & 1240 & 440 & 440 & 1440 & 240 \\
\hline Schedule receipts & 1000 & & 1000 & & 1000 & & 1000 & & 1000 & \\
\hline Planned order release & 1000 & & 1000 & & 1000 & & 1000 & & & \\
\hline
\end{tabular}

Table 16: Estimation of projected demand, scheduled receipt and planned order release of item I

\begin{tabular}{|l|l|l|l|l|l|l|l|l|l|l|}
\hline $\begin{array}{l}\text { Component I } \\
\text { Order quantity =500 } \\
\text { Lead Time = 2 weeks }\end{array}$ & 1 & 2 & 3 & 4 & 5 & 6 & 7 & 8 & 9 & 10 \\
\hline Projected requirement & 200 & 300 & & 500 & & 400 & & & 600 & \\
\hline Available = S S=120 & 620 & 420 & 120 & 620 & 120 & 620 & 220 & 220 & 720 & 120 \\
\hline Schedule receipt & 500 & & & 500 & & 500 & & & 500 & \\
\hline Planned order release & & 500 & & 500 & & & 500 & & & \\
\hline
\end{tabular}

\section{Conclusion:}

In this paper, a practical problem pertaining to material requirement planning was tried to solve. Starting with the product structure tree i.e. the bill of materials for making a component the projected requirement is estimated. From the scheduled receipt quantity the planned order release is estimated. This approach of solving the material requirement planning is of tremendous value in industrial sector. Thus exact material requirement planning is practiced. As a result the inventory control will be easy. Lot of money can be saved by exercising the material requirement planning like this way. The quantity discount facility will be availed. Money tied up in the inventory will be reduced. Material handling problem will be reduced. But the approach made in this paper does not provide solution to each \& every material requirement planning. Here in this case, the economic order quantity is not taken into consideration. The safety stock was not estimated. The lead time variation is not estimated. Moreover, the dependant inventory demand is not taken into consideration. The independent preparation of master schedule is not taken into consideration. Still, the paper tried its best to correlate the inventory decision like purchasing and storing with the production planning. The uniqueness of this paper is in the presentation of examples of actual scenario of industry. It will motivate the younger generation to 
take up the assignment on material requirement planning by correlating the production planning and inventory management problem.

\section{References:}

[1]. J Hoey, B.R. Kilmarting and R. Leonard (1986). Designing a Material Requirement Planning System to meet the needs of lowvolume, Make - to - order companies (with case study). Int. J. Prod. Res., 24, 2, 375-386.

[2]. James R. Ashby (1995). Scheduling and Order Release in a single stage production system. J. of manufacturing systems, 14, 4,290306.

[3]. A.G. Lagodimos and E.J. Anderson (1993). Optimal Positioning of Safety Stocks in MRP. Int. J. Prod. Res, 31, 8, 1797-1813.

[4]. W.C. Benton and R. Srivastava (1993). Product Structure complexity and inventory storage capacity on the performance of multilevel manufacturing system. Int. J. Prod. Res., 33, 11, 2531-2545.

[5]. Yenisey, M. M. (2006), A flownetwork approach for equilibrium of material requirements planning. International Journal of Production Economics, 102, pp 317-332.

[6]. Mula, J., Poler, R., and Garcia, G. P. (2006), MRP with flexible constraints: a fuzzy mathematical programming approach. Fuzzy Sets and System, 157, pp 74-97.

[7]. Wilhelm, W.E., Som, P. (1998), Analysis of a singlestage, singleproduct ,stochastic,MRPcontrolled assembly system. European Journal of Operational Research 108, pp 74-93

[8]. Axsäter, S. (2005), Planning order release for an assembly system with random

[9]. operations times.ORSpectrum, 27, pp 459-470.

[10]. Kanet JJ, Sridharan SV. (1998), the value of using scheduling information in planning material requirements. International Journal of Decision Science; 29, pp 479-96.

[11]. Kumar, A. (1989), Component inventory cost in an assembly problem with uncertain supplier leadtimes.IIE Transactions 21(2), pp $112-121$.

[12]. Chauhan, S.S., Dolgui, A., Proth, J.M.(2009), A continuous model for supply planning of assembly systems with stochastic component procurement times. International Journal of Production Economics 120, pp 411-417.

[13]. Van Donselaar, K.H., Gubbels, B.J. (2002), How to release orders in order to minimize system inventory and system nervousness? International Journal of Production Economics 78, pp 335-343.

[14]. Minifie JR, Davis RA. (1990), Interaction effects on MRP nervousness. International Journal of Production Research; 28, pp 17383.

[15]. Billington PJ, McClain JO, Thomas J. (1983), Mathematical programming approaches to capacity constrained MRP systems: review, formulation and problem reduction. Management Science; 29, pp1126-41. 